\title{
WYOBRAŹNIA TEUMACZA A NAOCZNOŚĆ ŚWIATA PRZEDSTAWIONEGO
}

\author{
JOANNA KUBASZCZYK
}

Związki między wyobraźnią a przekładem mogą być różnorakie. Anna Legeżyńska mówi o przekładzie jako rzeczy wyobraźni ${ }^{1}$. Zasadniczym pytaniem jest, czy tłumacz musi/powinien być człowiekiem o dobrze rozwiniętej wyobraźni? Gdyby zaś dobrze rozwinięta wyobraźnia miała być koniecznym atrybutem tłumacza, to czy warunkiem sine qua non dobrego przekładu jest spełnienie przez tłumacza określonych aktów wyobrażeniowych? Ponadto, o jaki rodzaj wyobraźni chodzi? Czy tylko o wyobrażenia odtwórcze czy też także twórcze?

W języku polskim funkcjonują obocznie trzy różne określenia władzy umysłowej, do której możemy się odnosić, mówiąc o wyobraźni, czyli wyobraźnia, fantazja i imaginacja. „Wyobraźnia” wydaje się być z nich pojęciem najszerszym, niejako nadrzędnym. Słownik Języka Polskiego definiuje ją jako „,zdolność do tworzenia wyobrażeń twórczych, przewidywania, uzupełniania i odtwarzania oraz zdolność przedstawiania sobie zgodnie z własną wolą sytuacji, osób, przedmiotów, zjawisk itp. nie widzianych dotąd; fantazja, imaginacja”" . „Imaginacja” jest pojęciem węższym, albowiem nie zawiera elementu odtwórczego, według SJP to ,zdolność wyobrażania sobie rzeczy nie istniejących albo nie widzianych, tworzenia obrazów lub sytuacji urojonych; wyobraźnia, fantazja”"3. Również „fantazja” kojarzona jest raczej z wyobraźnią twórczą, SJP wyjaśnia

\footnotetext{
${ }^{1}$ A. Legeżyńska, Ttumacz i jego kompetencje autorskie, Warszawa 1999, s. 216.

${ }^{2}$ Stownik Języka Polskiego, red. M. Szymczak, Warszawa 2004, s. 826. Dalej: SJP.

${ }^{3}$ Ibidem, s.775.
} 
znaczenie słowa jako ,zdolność do wyobrażania sobie czegoś; wyobraźnia twórcza; zmyślenie, urojenie, pomysł" .

Podczas gdy zatem „fantazja” i ,imaginacja” odnoszą się raczej do zdolności ludzkiego umysłu obrazowego przedstawiania sobie rzeczy nieistniejących albo niewidzianych i kojarzone są z wyobraźnią twórczą, to „wyobraźnia” bywa też odtwórcza. Pierwsze pytanie zatem, do którego jeszcze powrócimy, to, czy tłumacz musi być człowiekiem pełnym fantazji o rozbudowanych zdolnościach imaginacyjnych, innymi słowy człowiekiem wyobraźni twórczej czy raczej odtwórczej"

Inny podział rozróżnia między wyobraźnią mimowolną a dowolną ${ }^{6}$. Wyobraźnia mimowolna nie jest kierowana wolą, obrazy, które pojawiają się w umyśle opierają się na luźnych skojarzeniach, są ze sobą często (pozornie) niepowiązane, czego w skrajnej postaci doświadczyć można podczas marzeń sennych, czy też np. pod wpływem środków farmakologicznych. Wyobraźnia dowolna polega na świadomej i celowej umiejętności wywoływania w umyśle wyobrażeń $^{7}$. Rodzajem wyobraźni dowolnej jest wspomniana już wyobraźnia twórcza. Rozróżnia się tutaj ponadto wyobraźnię kierowaną ${ }^{8}$. Wyobraźnia twórcza wiąże się z umiejętnością wytwarzania nowych wyobrażeń, natomiast z wyobraźnią kierowaną mamy do czynienia $w$ przypadkach, gdy wyobrażenia odtwórcze i wytwórcze stymulowane są przez odpowiednie bodźce i sytuacje, np. przez odpowiednie opisy literackie, które prowokują generowanie obrazów ukierunkowując ich treść i zakres?.

Jeżeli więc mówimy o przekładzie jako rzeczy wyobraźni, to które z tych znaczeń mamy na myśli? Czy chodzi o wyobraźnię mimowolną czy może kierowaną? I czy wyobraźnia odgrywa rolę wyłącznie w przekładzie artystycznym czy może w przekładzie w ogóle, także w przekładzie tekstów użytkowych?

Immanuel Kant rozróżnia trzy podmiotowe źródła poznania, to jest zmysł, wyobraźnię i apercepcję ${ }^{10}$. Zmysł przedstawia zjawiska w sposób empiryczny w spostrzeżeniu, wyobraźnia przedstawia zjawiska w skojarzeniu i odtworzeniu,

\footnotetext{
${ }^{4}$ Ibidem, s. 572.

${ }^{5}$ Za Marią Przetacznik-Gierowską i Grażyną Makiełło-Jarżą o wyobraźni odtwórczej mówimy wtedy, gdy obrazy stanowią niewielką transformację obrazów percepcyjnych, w przypadku zaś, gdy pojawiające się obrazy są nowe i oryginalne, zakładamy, że są one wytworem wyobraźni twórczej. Obrazy odtwórcze (reprodukcyjne) można też uznać za wytwory procesów pamięci. Por. M. Przetacznik-Gierowska, G. Makiełło-Jarża, Podstawy psychologii ogólnej, Warszawa, 1989, s. $129-130$.

${ }^{6}$ Ibidem, s. 130.

${ }^{7}$ Ibidem, s. 130.

${ }^{8}$ Ibidem, s. 130-131.

${ }^{9}$ Ibidem, s. 131.

${ }^{10}$ Por. I. Kant, Kritik der reinen Vernunft, red. R. Schmidt, Hamburg, 1956, KrV A 115.
} 
zaś apercepcja ukazuje tożsamość przedstawień odtwórczych ze zjawiskami, dzięki którym są one dane. Według Kanta wrażenia, które powstają poprzez oglądanie przedmiotów czy innego rodzaju zmysłowy kontakt z nimi, są rezultatem oddziaływania przedmiotu na zdolność wyobrażania sobie. Innymi słowy bez funkcji mózgu, nazywanej wyobraźnią, niemożliwe byłoby łączenie, uporządkowanie i rozpoznanie danych zmysłowych. Jasno rysuje się tu też połączenie wyobraźni z pamięcią, bez której niemożliwa do spełnienia byłaby reproduktywna, czyli odtwórcza, i skojarzeniowa funkcja wyobraźni. Człowiek wchodząc w zmysłowy kontakt z przedmiotami uzyskuje doświadczenie empiryczne, oparte na wrażeniach. Zmysłowość dostarcza mu danych naocznych, a te są intelektualnie przetwarzane, czyli nadawany jest im kształt myślowy w formie pojęcia. Ważną rolę odgrywa przy tym rozróżnienie między materią, czyli tym, co w zjawisku czy przejawie odpowiada wrażeniu, a formą zjawiska, czyli tym, co różnorodne. Podczas gdy materia jest dana człowiekowi a posteriori, forma musi tkwić a priori w umyśle, stąd możliwość myślenia o niej w oderwaniu wszelkiego doświadczenia.

Zasadniczo ustalenia Kanta są istotne również dla teorii przekładu, albowiem przekład jest możliwy wyłącznie dlatego, że człowiek może pomyśleć coś, czego nie doświadczył, np. może pomyśleć o waranie, nigdy zmysłowo nie doświadczywszy warana, albo a priori intelektualnie ustalić konieczność istnienia jakiegoś elementu rzeczywistości (np. planety w systemie astronomicznym), które to intelektualne ustalenie często wyprzedza doświadczenie. Jest w stanie również abstrahować od materii wielu jednostkowych wrażeń, czyli doświadczeń empirycznych, czyli potrafi oderwać formę od materii, np. na podstawie wielu różnych danych naocznych dotyczących jednostkowych kotów może myśleć o kocie w ogóle.

Czy zatem - zapytam przewrotnie - tłumacz jako istota potrafiąca operować pojęciami potrzebuje w ogóle w swej pracy odwoływać się do wyobraźni? Pytanie to nie jest niezasadne, albowiem tłumacz nie jest skonfrontowany zwykle z daną bezpośrednio naocznością faktów zmysłowych, lecz z pojęciami (oczywiście przekazywanymi też w sposób naoczny za pomocą odpowiedniego kanału komunikacyjnego, czyli mowy - wrażenia audytywne - lub pisma - wrażenia wzrokowe, ale od tego tu abstrahujemy). Zanim spróbujemy odpowiedzieć na to pytanie, chciałabym przywołać pierwszy z przykładów, w którym autor explicite odwołuje się do wyobraźni, wskazując też na jej ograniczenia ze względu na brak doświadczenia empirycznego. Ma zatem na myśli raczej wyobrażenia odtwórcze, czyli polegające na skojarzeniu i odtworzeniu odpowiedniego wrażenia niż twórcze:

Zu der Zeit, von der wir reden, herrschte in den Städten ein für uns moderne Menschen kaum vorstellbarer Gestank. Es stanken die Straßen nach Mist, es stanken die Hinter- 
höfe nach Urin, es stanken die Treppenhäuser nach fauligem Holz und nach Rattendreck, die Küchen nach verdorbenem Kohl und Hammelfett [...]. ${ }^{11}$

W epoce, o której mowa, miasta wypełniał wprost niewyobrażalny dla nas, ludzi nowoczesnych smród. Ulice śmierdziały łajnem, podwórza śmierdziały uryną, klatki schodowe śmierdziały przegniłym drewnem i odchodami szczurów, kuchnie - skisłą kapustą i baranim łojem $[\ldots]^{12}$.

Teza Süskinda, że panujący ówcześnie smród jest dla nas ludzi nowoczesnych prawie niewyobrażalny, znajduje paradoksalnie potwierdzenie w przekładzie: tłumaczka ewidentnie nie doświadczyła jak śmierdzi zepsuta kapusta. Czy jednak musiała? Czy bez tego doświadczenia, którego nie posiadając nie mogła uaktualnić mocą wyobraźni, przekład był skazany w tym punkcie na fiasko? Oczywiście nie, ponieważ Süskind użył środków języka odsyłających nas przez przypisane im znaczenie, do pojęcia, do wyobrażenia i do rzeczywistości pozajęzykowej. Czyli teoretycznie tłumaczka mogła przetłumaczyć ten fragment dosłownie, odsyłając czytelnika do odpowiedniego pojęcia i ewentualnie pozwalając mu zrekonstruować mocą wyobraźni odpowiednie wrażenie. A jednak niemożność wyobrażenia sobie, wynikająca z braku doświadczenia empirycznego, doprowadziła do fiaska. Dlaczego? Bo tłumaczka nie uwierzyła autorowi? (Nie uwierzyła, bo nie doświadczyła?) Bo przekład to też rzecz interpretacji? Bo przeszkodziła jej wyobraźnia, nasuwająca inny obraz, reaktywująca inne wrażenie zmysłowe? Pytanie zatem, czy można przekładać nie odwołując się do wyobraźni, można poniekąd sparafrazować pytając, czy można mówić ze ślepym o kolorach? Teoretycznie można, praktycznie jest to jednak bardzo trudne. Ale przykład ten sugeruje jeszcze jedną rzecz: nieodpowiednio ukierunkowana wyobraźnia może też czasami przeszkadzać, wytwarzając zafałszowaną naoczność.

Tłumacz skonfrontowany jest z tekstem, odsyłającym przez język do pojęć i obrazów. W rozważaniach nad wyobraźnią w przekładzie interesujące jest stąd, czy i na ile dla dobrego przekładu konieczne jest sprzęganie pojęć w umyśle tłumacza z uaktualnianiem doświadczeń empirycznych lub wytwarzaniem mocą skojarzeń wyobrażeń nowych na bazie doświadczeń empirycznych bezpośrednio niezwiązanych $\mathrm{z}$ danym pojęciem.

Wyobrażenia są treścią świadomości, które mogą odnosić się albo do przeszłości jako wspomnienia rzeczywistych postrzeżeń albo do przyszłości jako oczekiwania czy obawy albo bez konkretnego odniesienia do rzeczywistości i czasu jako obrazowe wyobrażenia abstrakcyjnych idei. Źródłem wszelkiego

\footnotetext{
${ }^{11}$ P. Süskind, Das Parfum. Die Geschichte eines Mörders, Zürich 1985, s. 5, wytł. JK.

${ }^{12}$ P. Süskind, Pachnidło. Historia pewnego mordercy, przeł. M. Łukasiewicz, Warszawa 1996, s. 5, wytł. JK.
} 
wyobrażenia jest jednak wcześniejsze doświadczenie zmysłowe, które przywoływane jest w umyśle (w wyobraźni) podmiotu albo jako (unaoczniające) wspomnienie albo $\mathrm{w}$ formie przetworzonej jako transformacja doświadczeń zmysłowych. Wyobrażenia te nie mają zwykle formy jednostkowych obrazów, lecz mają złożoną strukturę, co sprawia, że czasami widzimy oczyma wyobraźni całe sekwencje obrazów niczym wewnętrzny film. Choć w przeważającej części wyobrażenia kojarzone są z obrazami i zespołami obrazów, to jednak nie mają one wyłącznie wizualnego charakteru. Obraz ewokowany w wyobraźni jest zwykle, bądź przynajmniej może być, zespołem przywołanych, uaktywnionych i często na nowo zmiksowanych wrażeń zmysłowych różnego rodzaju - wizualnych, audytywnych, taktylnych, olfaktorycznych, gustatorycznych, mówi się stąd o wyobrażeniach wzrokowych, słuchowych, smakowych, węchowych i dotykowych. Wyobrażenia te są jednak zwykle schematyczne, choć w zależności od sprawności władzy zwanej wyobraźnią - mogą różnić się znacznie i sięgać od wyobrażeń o dużym stopniu schematyczności do wyobrażeń bardzo szczegółowych. Wyobrażenie „kota” może np. opierać się na schemacie i przywoływać prototypowego kota, nieuszczegółowionego, a może być też realizowane jako wyobrażenie bardzo konkretnego, specyficznie umaszczonego, miękkiego w dotyku, pachnącego i miauczącego w określony sposób, poruszającego się swoiście kociaka. Może on przypominać kota z otoczenia podmiotu wyobrażającego go sobie, ale też może być konglomeratem różnych treści postrzeżeniowo-wyobrażeniowych.

Wyobrażenia mogą być samoistne, mimowolne, lub stymulowane i sterowane wolitywnie. Ważne jest, by pamiętać o tym rozróżnieniu, gdyż pod wpływem różnych czynników mimowolne wyobrażenia czytelnika-tłumacza mogą różnić się zasadniczo od wyobrażeń zamierzonych/założonych przez autora tekstu. Te mimowolne wyobrażenia mogą powstać np. pod wpływem błędnej interpretacji semantycznej danego leksemu, szczególnie wtedy, gdy na sumę znaczeń składowych nakłada się znaczenie naddane, komponent idiosynkratyczny, jak to ma miejsce choćby w derywatach asocjacyjnych i wielu niemieckich złożeniach, których nie można interpretować tylko jako sumy znaczeń elementów składowych. W powieści Grassa Die Rättin główny bohater siedzi w wózku inwalidzkim, tłumacz przekłada jednak leksem Rollstuhl jako fotel na kółkach:

Während ich in einem Rollstuhl angeschnallt saß, schrie ich, als wäre im Traum ein Lautsprecher greifbar gewesen: Wir sind da! ${ }^{13}$

Siedząc przypięty w fotelu na kółkach krzyczałem, jak gdybym we śnie miał dostęp do megafonu: My jesteśmy! ${ }^{14}$

\footnotetext{
${ }^{13}$ G. Grass, Die Rättin, Darmstadt/Neuwied 1986, s. 31, wytł. JK.

${ }^{14}$ G. Grass, Szczurzyca, przeł. S. Błaut, Gdańsk 2001, s. 28, wytł. JK.
} 
Kurz nach sieben werde ich mit Hilfe des Weckers aufwachen, diesen verdammt gemütlichen Rollstuhl, in dem ich wie angeschnallt sitze, verlassen und meinen Tag [...] beginnen. $^{15}$

Krótko po siódmej obudzę się z pomocą budzika, opuszczę ten piekielnie wygodny fotel na kółkach, w którym siedzę jakby przypięty pasami, i mój dzień [...] zacznę [...] ${ }^{16}$

W tym przypadku trudno rozstrzygnąć, co było pierwsze, mimowolne wyobrażenie, które wpłynęło na mylną interpretację znanego przecież powszechnie leksemu, czy też fałszywa interpretacja semantyczna, która w konsekwencji doprowadzić musiała do błędnego wyobrażenia. Trudno jednak zakładać, że tłumacz tej rangi nie znał tak popularnego słowa jak niemieckie określenie wózka inwalidzkiego, choć oczywiście i takiej ewentualności nie da się wykluczyć. Dlatego wydaje się, że pierwsza interpretacja, iż tłumacz poddał się mimowolnemu wyobrażeniu ewokowanemu przez słowo Stuhl, czyli fotel, wzmocnionemu jeszcze przez opis, iż ów Rollstuhl (czyli dosłownie: „toczący się fotel”) był „piekielnie wygodny”, jest bardziej prawdopodobna. Obojętnie jednak czy źródłem było mimowolne wyobrażenie czy też tylko błędna interpretacja leksykalna bez towarzyszącego wyobrażenia, to z pewnością tego rodzaju błąd wpłynie na wywołanie zupełnie innego wyobrażenia u odbiorców przekładu.

Mimowolne skojarzenie i wyobrażenie stało się przyczyną błędu również w kolejnym przykładzie, w którym mowa o kwiatach wielkości główek kapusty. Ponieważ w rzeczywistości porównywalną wielkość mają słoneczniki, tłumacz najprawdopodobniej mimowolnie wyobraził je sobie i nie skorygował tego wyobrażenia przez wyobrażenie sterowane wolitywnie, mające oparcie w warstwie leksykalnej tekstu, w którym mowa jest o makach wielkości główki kapusty. $\mathrm{Na}$ skutek tego ponownie błędne wyobrażenie tłumacza prowadzi do rozbieżnych z oryginałem wyobrażeń czytelników przekładu:

Das neue Kleid hält die Mutter immer noch in der zitternden Hand. Wenn sie es verkaufen will, muß sie das bald tun, denn solche kohlkopfgroßen Mohnblumen trägt man nur ein Jahr und nie wieder. ${ }^{17}$

Nową sukienkę wciąż jeszcze matka trzyma w drżącej dłoni. Jeśli Erika chce ją sprzedać, to musi to zrobić jak najszybciej, bo takie słoneczniki wielkości główki kapusty nosi się tylko jednego roku i nigdy potem ${ }^{18}$.

Przykłady te pokazują, że tłumacz musi korygować wywołane ewentualnie lekturą tekstu wyobrażenia samoistne, mimowolne, które mu się nasuwają na

\footnotetext{
${ }^{15}$ G. Grass, Die Rättin, s. 33, wytł. JK.

${ }^{16}$ G. Grass, Szczurzyca, s. 29, wyt1. JK.

${ }^{17}$ E. Jelinek, Die Klavierspielerin, Reinberg bei Hamburg 2005, s. 12.

${ }^{18}$ E. Jelinek, Pianistka, przeł. R. Turczyn. Warszawa 2004, s. 11.
} 
zasadzie wolnych skojarzeń. W procesie (wielokrotnej) lektury powinien stymulować wyobrażenia odpowiadające w miarę ściśle instrukcjom tekstowym. Innymi słowy musi on procesem wyobraźni sterować wolitywnie i konfrontować swoje spontaniczne, samoistnie nasuwające się mu wyobrażenia $\mathrm{z}$ wyobrażeniami (wtórnymi) wynikającymi z logicznej analizy tekstu. W przypadku przekładu ważną rolę odgrywa stąd dyscyplina wyobraźni. Mówiąc o dyscyplinie wyobraźni mam na myśli wyobrażenia ukierunkowane, poddane instrukcjom tekstu, a nie bazujące wyłącznie na pewnych jego elementach. Często tego rodzaju mimowolne wyobrażenia powstają przez niedokładne czytanie, ale przyczyn kognitywnych jest oczywiście dużo więcej, jak choćby mimowolna korekta kalibrująca bodziec z rzeczywistością, z tym co znane (ten mechanizm mógł wystąpić w przypadku maków wielkości główki kapusty).

A zatem, gdy mowa o wyobraźni w przekładzie, idzie o wyobraźnię kierowaną. Dane słowo, struktura czy forma stanowi przy tym dźwignię wyobraźni, by użyć terminu Piotra Markiewicza i Piotra Przybysza, stanowi więc „typ wyzwalacza procesów wyobrażeniowych lub stymulator takich procesów"19.

Oparte na konwencjonalnym skojarzeniu mimowolne wyobrażenie prowadzi do częstych błędów w przekładzie. Błędy takie pojawiają się szczególnie wtedy, gdy w opisie użyte są wyrazy mniej znane, względnie w ogóle nieznane tłumaczowi i tłumacz wyobrażając sobie scenę kompleksowo bazuje na pewnym stereotypie. Ten mechanizm zadziałał najprawdopodobniej w umyśle tłumaczki, która przekładając następujący opis konwencjonalnie skojarzyła pieska, radość i podniecenie $\mathrm{z}$ merdaniem:

Als erstes probierte er es mit einem kleinen Hund. Drüben vor dem Schlachthaus lockte er ihn mit einem Stück Fleisch von seiner Mutter weg bis in die Werkstatt, und während das Tier mit freudig erregtem Hecheln nach dem Fleisch [...] schnappte, schlug er ihm [...] kurz und derb auf den Hinterkopf. ${ }^{20}$

Na początek spróbował z małym psiakiem. W pobliżu rzeźni za pomocą ochłapu mięsa odciągnął go daleko od matki i podczas gdy zwierzę z radosnym merdaniem chwytało mięso [...] zadał mu szybki cios w tył głowy ${ }^{21}$.

Hecheln natomiast nie oznacza merdania tylko ziajanie, dyszenie. Pies zatem radośnie dyszał, ziajał.

Przykład ten pokazuje, że znajomość typowych, skonwencjonalizowanych scen i scenariuszów, zwykle pomocna w przekładzie, może wpłynąć na przekład negatywnie, gdy tłumacz zbyt mocno się nimi (często podświadomie) sugeruje.

\footnotetext{
${ }^{19}$ P. Markiewicz, P. Przybysz, Neuroestetyczne aspekty komunikacji wizualnej i wyobraźni, w: Obrazy w umyśle. Studia nad percepcja i wyobraźnią, red. P. Francuz, Warszawa 2007, s. 135.

${ }^{20}$ P. Süskind, Das Parfum, s. 236, wytł. JK.

${ }^{21}$ P. Süskind, Pachnidło, s. 186, wytł. JK.
} 
Jednocześnie we fragmencie tym widzimy, że tłumaczka wyobraża sobie przestrzeń przedstawioną dużo mniej dokładnie niż opisuje ją Süskind, stąd obraz, który wywołuje opis w oryginale, jest lepiej umiejscowiony w przestrzeni. Obraz ten jest realistyczny i na jego podstawie można by bez problemu nakręcić film fabularny, natomiast $\mathrm{w}$ polskim przekładzie mamy do czynienia $\mathrm{z}$ rozmazaniem konturu, z obrazem impresjonistycznym, by użyć malarskiego porównania. Z polskiego przekładu dowiadujemy się bowiem jedynie, że wszystko działo się w okolicy rzeźni, natomiast autor pisze, że Grenouille zwabił pieska sprzed rzeźni po drugiej stronie (ulicy) aż do warsztatu, odciągając go od matki za pomocą kawałka mięsa. Autor oryginału wskazuje też, że zabicie nastąpiło nie tylko szybko, ale i brutalnie, a zatem i w tym aspekcie obraz jest bardziej uszczegółowiony. Dyscyplina wyobraźni dotyczy zatem również odpowiedniego uszczegółowienia wyobrażeń. Nie wystarczy, by tłumacz pobieżnie, z grubsza, impresjonistycznie, wyobraził sobie jakąś scenę, ale musi zrobić to w miarę detalicznie.

Jednak tłumaczka Pachnidta wydaje się mieć nie tylko w tym fragmencie problemy z wyobrażeniem sobie przestrzeni przedstawionej, co czasami skutkuje jak powyżej ,rozmazaniem” przestrzeni, czasami sprawia, że elementy tej przestrzeni są ustawione w stosunku do siebie w innych niż opisane w oryginale relacjach, a czasami prowadzi do opisów kuriozalnych, gdyby je sobie chcieć właśnie wyobrazić. $\mathrm{Z}$ drugą $\mathrm{z}$ wymienionych sytuacji mamy np. do czynienia we fragmencie, w którym mistrz perfumeryjny Baldini wyprowadza Grenouille'a na zewnątrz z warsztatu. Wychodzą przez sklep, z którego wąski korytarz prowadzi do wejścia dla posłańców. Starzec zmierza powłócząc i szurając nogami, człapiąc, w kierunku bramy, odsuwa zasuwę i ustępuje na bok, by wypuścić chłopaka:

Und er nahm einen der Leuchter und ging zur Tür hinaus, hinüber in den Laden. Grenouille folgte ihm. Sie kamen in den schmalen Korridor, der zum Dienstboteneingang führte. Der Alte schlurfte auf die Pforte zu, riß den Riegel zurück und öffnete. Er trat beiseite, um den Jungen hinauszulassen. ${ }^{22}$

Ten opis i ewokowany przez niego obraz ulega przemianie w przekładzie. Nie tylko starszy pan jest bardziej zażywny i drepcze do drzwi, ale ma się też wrażenie, że korytarz jest węższy, albowiem Baldini ustępuje nie na bok, a do tył. Na skutek tego w połączeniu z wejściem dla dostawców (zamiast bramy dla posłańców) obraz jest nieco mniej prawdopodobny niż obraz oryginału, bo trzeba by sobie wyobrazić dostawców przeciskających się bardzo wąskim korytarzem (co tłumaczka podkreśla, używając deminutivum), ale z punktu widzenia logiki jest jeszcze akceptowalny:

Ujął jeden z lichtarzy, ruszył do drzwi i przeszedł do pomieszczenia sklepowego. Grenouille podążał za nim. Znaleźli się w wąskim korytarzyku, który wiódł do wejścia

\footnotetext{
${ }^{22}$ P. Süskind, Das Parfum, s. 110, wytł. JK.
} 
dla dostawców. Baldini podreptał do drzwi, odsunął rygiel i otworzył. Cofnął się, aby wypuścić chłopca ${ }^{23}$.

Obraz ten, mimo że rozbieżny z obrazem wykreowanym w oryginale, nie prowadzi zasadniczo do inkoherencji na poziomie obrazowania. Inaczej rzeczy się mają w kolejnym przykładzie, dynamicznej i pełnej ekspresji scenie porodu na targowisku przy Rue aux Fers:

Grenouilles Mutter stand, als die Wehen einsetzten, an einer Fischbude in der Rue aux Fers und schuppte Weißlinge [...]. [...]. Und als die Wehen einsetzten, hockte sie sich unter ihren Schlachttisch und gebar dort, wie schon vier Mal zuvor und nabelte mit dem Fischmesser das neugeborene Ding ab. Dann aber, wegen der Hitze und des Gestanks, den sie als solchen nicht wahrnahm, sondern nur als etwas Unerträgliches, Betäubendes - wie ein Feld von Lilien oder wie ein enges Zimmer, in dem zuviel Narzissen stehen -, wurde sie ohnmächtig, kippte zur Seite, fiel unter dem Tisch hervor mitten auf die Straße und blieb dort liegen, das Messer in der Hand. ${ }^{24}$

Gdy zaczęły się bóle, matka Grenouille'a stała za straganem rybnym przy ulicy aux Fers i skrobała ukleje [...]. [...]. I kiedy zaczęły się bóle parte, przykucnęla za blatem do oprawiania ryb i tam, podobnie jak cztery razy przedtem, urodziła i nożem od ryb odcięła pępowinę. Potem jednak, na skutek upału i smrodu, których jako takich w ogóle nie postrzegała, a tylko czuła nieznośną duchotę - jak na polu lilii albo w ciasnym pomieszczeniu, gdzie postawiono za dużo narcyzów - straciła przytomność, osunęla się na ziemię i legła pod straganem, na środku ulicy, z nożem w garści ${ }^{25}$.

Porównanie opisów miejsca i przebiegu akcji w tekście oryginału i w polskim przekładzie wykazuje spore różnice. W oryginale matka Grenouille'a stoi przy straganie z rybami. Gdy zaczyna się poród, kuca pod ladą, a nie za ladą, co ma wpływ na dalsze kształtowanie obrazu. Po porodzie traci przytomność, przewraca się na bok i wytacza się (czy dokładniej wypada) spod stołu na środek ulicy, gdzie zaczyna otaczać ją gawiedź. W przekładzie rysuje się obraz zgoła odmienny i raczej niezrozumiały, bo skoro legła pod straganem, to dlaczego na środku ulicy, czy stragan stał na środku ulicy? Gdy czytamy ten fragment przekładu, odnosimy wrażenie, że tłumaczkę zawiodła właśnie wyobraźnia, że nie zrekonstruowała ona w wyobraźni obrazu opisanego przez Süskinda.

Podobny problem, tym razem związany z pominięciem ważnej informacji dotyczącej ustawienia przedmiotów w przestrzeni, mamy w kolejnym fragmencie tej samej powieści, w którym opisane jest małe kwadratowe podwórko. Do muru przylega skośny drewniany dach, skierowany ku podwórzu. Na stole pod dachem przylepiona jest świeca. Pod dachem siedzi trzynastoletnia może dziew-

\footnotetext{
${ }^{23}$ P. Süskind, Pachnidto, s. 88, wytł. JK.

${ }^{24}$ P. Süskind, Das Parfum, s.7-8, wytt. JK.

${ }^{25}$ P. Süskind, Pachnidło, s. 8, wytt. JK.
} 
czynka i czyści mirabelki. Po lewej stronie ma kosz, z którego wyjmuje owoce. Pewnie po prawej wiaderko, do którego wrzuca wydrylowane mirabelki:

Der Platz umfaßte nur wenige Schritte im Geviert. An der Mauer sprang ein schräges Holzdach vor. Auf einem Tisch darunter klebte eine Kerze. Ein Mädchen saß an diesem Tisch und putzte Mirabellen. Sie nahm die Früchte aus einem Korb zu ihrer Linken, entstielte und entkernte sie mit einem Messer und ließ sie in einen Eimer fallen. ${ }^{26}$

Opis w tekście niemieckim jest wystarczająco precyzyjny, by wyobrazić sobie tę scenę dokładnie. $\mathrm{Z}$ przekładu polskiego natomiast ani nie dowiadujemy się, jaki kształt ma podwórko, ani że dach ma formę wykuszu, że przylega do muru, ani jak usytuowany jest względem postaci kosz. Dowiadujemy się, że z jednej strony sterczał daszek, ale bez żadnego odniesienia do pozostałych elementów przestrzeni, trudno sobie zatem wyobrazić, jak by to miało wyglądać:

Placyk liczył ledwie kilka kroków wzdłuż i wszerz. Z jednej strony na pewnej wysokości sterczał ukośny drewniany daszek. Na stole pod daszkiem stała umocowana świeca. Przy stoliku siedziała młodziutka dziewczyna i przebierała mirabelki. Lewą ręką wyjmowała owoce z kosza, nożykiem drylowała je z pestek i wrzucała do cebrzyka ${ }^{27}$.

$\mathrm{Na}$ koniec odniosę się jeszcze do uszczegółowienia wyobrażeń. Choć powyżej postulowałam, by tłumacz posiadał lub rozwijał w sobie wyobraźnię detaliczną (detalu), to zasadniczo, jak się wydaje, niekoniecznym jest, by wyobrażenie, które dany opis ewokuje w umyśle tłumacza, było zawsze maksymalnie ukonkretnione. W dużej mierze stopień uszczegółowienia wyobrażenia zależy od przekładanego tekstu i stopnia uszczegółowienia opisu w tymże tekście. Tłumacz, który zamierza zmierzyć się z tekstem Wisławy Szymborskiej Kot $w$ pustym mieszkaniu nie musi sobie wyobrażać tytułowego kota konkretnie, wystarczy pewien schematyczny obraz prototypowego kota, by unaocznić sobie opisywaną przez Szymborską sytuację:

Umrzeć - tego nie robi się kotu.

Bo co ma począć kot

W pustym mieszkaniu.

Wdrapywać się na ściany.

Ocierać między meblami.

Nic niby tu nie zmienione, a jednak pozamieniane.

Niby nie przesunięte,

a jednak porozsuwane.

I wieczorami lampa już nie świeci ${ }^{28}$.
Sterben - das tut man einer Katze nicht an.

Denn was soll die Katze

In einer leeren Wohnung.

An den Wänden hoch,

sich an Möbeln reiben.

Nichts scheint hier verändert,

und doch ist alles anders.

Nichts verstellt, so scheint es, und doch alles auseinandergeschoben.

An den Abenden brennt die Lampe nicht mehr. ${ }^{29}$

${ }^{26}$ P. Süskind, Das Parfum, s. 53.

${ }^{27}$ P. Süskind, Pachnidto, s. 43.

${ }^{28}$ W. Szymborska, Hundert Gedichte - Hundert Freuden. Sto wierszy - sto pociech, przeł. K. Dedecius, Kraków 2005, s. 272-274, wytł. JK. 
Do tego schematycznego wyobrażenia kota przynależą też typowe kocie zachowania, do których poetka się w swoim tekście odwołuje: wdrapywanie się i ocieranie. Czy tłumacz wyobraził je sobie? Trudno powiedzieć. Analiza przekładu wskazuje jednak, że może wyobraził sobie tę scenę zbyt schematycznie, a przynajmniej czytelnik przekładu, ,widzi” obraz dużo mniej konkretny, obraz ukierunkowania w górę, pewną abstrakcję. Zasadniczo w języku niemieckim istnieją jednak zleksykalizowane opisy, pozwalające dosyć adekwatnie wyobrazić sobie opisywaną scenę (takie jak eine Katze streckt sich an Wänden hoch, richtet sich an Wänden auf), stąd przyczyną nie jest w tym wypadku materia języka i możliwości tworzywa.

Również w drugim przypadku wyobrażenie wywoływane przez przekład odrobinę się różni od wyobrażenia ewokowanego przez oryginał. Mieszkanie Szymborskiej sprawia wrażenie bardziej zagraconego, kot ociera się nie o meble, tylko między meblami, co oznacza, że meble w przestrzeni przedstawionej stoją stosunkowo blisko siebie, na odległość kota. W tym kontekście symptomatyczne jest „porozsuwanie” jako obraz emocjonalnego oddalenia, zwiększenia dystansu. W polskim tekście poetka konsekwentnie nadbudowuje sens metaforyczny na konkretnym opisie przestrzeni, w przekładzie jeden obraz nie uzasadnia drugiego.

Jednak problem jest tutaj bardziej złożony i dotyczy również konwencjonalności wyobrażeń, także konwencjonalności pewnych wyobrażeń utrwalonych językowo. O ile w języku niemieckim skonwencjonalizowany jest obraz (kociego) ocierania się o coś, mając w planie wyrażania odpowiedni eksponent, to nie ma skonwencjonalizowanego wyrażenia na ocieranie się między. W sposób skonwencjonalizowany mówi się, że Die Katze streicht an Möbeln entlang, um Möbel, streicht um Möbel herum. By zachować w miarę wiernie obraz z wiersza Szymborskiej można by ewentualnie zmodyfikować nieco opis, mówiąc, że kot skrada się ocierając się między meblami (Sie schleicht streichend zwischen den Möbeln).

Poszukiwanie rozwiązań tam, gdzie systemy językowe są, jak w powyżej różne, to także niezwykle interesujący, jak sądzę, aspekt wyobraźni. Wyobraźnia w tym przypadku stanowi jednocześnie ,dyspozycję do dostrzegania wieloznaczności i wielości rozwiązań” ${ }^{30}$ oraz „operację dokonywaną na istniejącym materiale, związaną z twórczym przetasowaniem elementów, nowym ich łączeniem ze sobą oraz «dopowiadaniem» i dodawaniem nowych elementów do istniejącego wzorca"31. Jej szczególną odmianą jest wyobraźnia formalna jako specyficzny rodzaj wyobraźni twórczej tłumacza. Dochodzi ona do głosu szcze-

\footnotetext{
${ }^{29}$ Ibidem, s. 273-275, wytł. JK.

${ }^{30}$ P. Markiewicz, P. Przybysz, op. cit., s. 136.

${ }^{31}$ Ibidem, s. 136.
} 
gólnie tam, gdzie nie ma gotowych rozwiązań formalnych, a materia języka wraz z obrazowaniem konwencjonalnym zdaje się uniemożliwiać przeniesienie formy czy obrazu z tekstu oryginału do tekstu przekładu i odtworzenie gry wyobraźni.

Ulla Fix wyróżnia trzy rodzaje naoczności, naoczność przez znaczenie słowa, kiedy to samo znaczenie sprawia, że widzimy oczyma wyobraźni określone treści, naoczność przez formę, realizowaną szczególnie przez ikoniczne użycie znaków językowych oraz naoczność przez uogólnienie, przez metaforyczne przeniesienie $^{32}$. Jednocześnie uważa ona, jak najbardziej słusznie, że obrazonośny charakter mają w sposób spotęgowany słowa, które nie znajdują się w centrum pola leksykalnego jako archileksemy, lecz na jego skraju. Używając wprowadzonego wcześniej terminu możemy powiedzieć, że to one są w sposób szczególny dźwigniq wyobraźni. W niniejszym artykule skupiłam się wyłącznie na przykładach ilustrujących obrazowanie za pomocą znaczenia słów, pokazując, że lekceważenie przez tłumacza przypisanych słowom znaczeń prowadzi zasadniczo do utraty naoczności bądź do jej zafałszowania w przekładzie.

Jak starałam się pokazać, wyobraźnia, służąca - jak to metaforycznie ujmują Elżbieta Zdankiewicz-Ścigała i Tomasz Maruszewski m.in. „do odgrywania w umyśle scen”, tworzenia ,teatru w umyśle"33 jest ważną władzą, niezwykle pomocną tłumaczowi, ale musi być to wyobraźnia trzymana w ryzach, podporządkowana wyobraźni autora, wyobraźnia dowolna, kierowana i kontrolowana, a nie mimowolna bądź w sposób autorski twórczo wyzwolona.

\footnotetext{
${ }^{32}$ U. Fix, An-schauliche Wörter? Wörter im Dienste der ,Bildhaftigkeit', ,Bildlichkeit', ,Bildkräftigkeit', ,Sinnlichkeit', ,Lebendigkeit', ,Gegenständlichkeit'von Texte, w: Das Wort in Text und Wörterbuch, red. I. Barz, U. Fix, G. Lerchner, Leipzig 2002, s. 18-22.

${ }^{33}$ E. Zdankiewicz-Ścigała, T. Maruszewski, Wyobrażenia jako pierwsza forma doświadczenia generowanego przez jednostkę, w: Psychologia. Podręcznik akademicki, red. J. Strelau, Gdańsk 2000, s. 184.
} 


\title{
HORRORY TEUMACZENIOWE CZY TŁUMACZE Z PIEKŁA RODEM? CZYLI KILKA SŁÓW O EFEKTYWNOŚCI KOMUNIKACJI INTERLINGWALNEJ
}

\author{
ALEKSANDRA MATULEWSKA
}

\section{Wprowadzenie}

Niniejsza praca ma na celu przedstawienie problemu efektywności komunikacji w świetle błędu dyskwalifikującego przekład nazywanego również błędem krytycznym (ang. fatal error) (Biel 2012, Dybiec-Gajer 2013) lub kardynalnym (Hejwowski 2004) w tekstach specjalistycznych. Najpierw zostanie przedstawiony krótki przegląd typologii błędów przekładowych. Następnie w zarysie zostanie omówiona efektywności komunikacji językowej. Na koniec zostaną przedstawione przykłady błędów krytycznych w oparciu o klasyfikację Hejwowskiego (2004). Praca została oparta na analizie literatury przedmiotu.

\section{Efektywność komunikacji znakowej}

Aby móc mówić o efektywności komunikacji trzeba sobie uświadomić, że

„efektywność komunikacji znakowej można rozumieć jako zgodność zamierzenia nadawcy znaku z treścią zrekonstruowaną przez odbiorcę" (Bańczerowski, Pogonowski, Zgółka 1982: 38).

Należy mieć świadomość, że znaki to zjawiska o charakterze kulturowym. Są one przejawem konwencji kulturowych i dlatego by móc je właściwie rozu- 